\title{
Penjadwalan Berdasarkan Analisis Faktor- Faktor Penyebab Keterlambatan Proyek Reparasi Kapal: Studi Kasus MV. Blossom
}

\author{
Laura Karennina Padaga, Imam Rochani, dan Yeyes Mulyadi \\ Departemen Teknik Kelautan, Fakultas Teknologi Kelautan, Institut Teknologi Sepuluh Nopember (ITS) \\ e-mail:imamr@oe.its.ac.id
}

\begin{abstract}
Abstrak-Reparasi kapal merupakan sebuah proyek yang singkat dalam prosesnya sehingga waktu merupakan elemen kritis sebagai parameter penyelesaian. Keterlambatan waktu merupakan suatu peristiwa yang dapat terjadi pada setiap proyek. Suatu proyek cenderung mengalami keterlambatan apabila buruknya manajemen proyek dan juga kesalahankesalahan yang disebabkan oleh sumber daya manusia didalamnya. Studi ini menganalisa faktor penyebab keterlambatan pada proyek reparasi kapal MV. Blossom dengan menggunakan metode Fault Tree Analysis (FTA) serta membuat rencana baru penjadwalan proyek agar dapat dijadikan sebagai acuan supaya proyek dapat selesai sesuai dengan jangka waktu yang telah ditentukan dengan menggunakan Critical Path Method (CPM). Dari hasil analisa metode FTA didapatkan tiga peluang basic event penyebab utama keterlambatan proyek sebesar 0.33196 untuk peralatan kerja terbatas, 0.22502 untuk peralatan jarang dirawat, dan 0.12393 untuk jumlah tenaga kerja kurang. Untuk hasil penjadwalan ulang dengan CPM didapatkan bahwa proyek dapat selesai dalam waktu 41 hari yang semula berdurasi 101 hari.
\end{abstract}

Kata Kunci-critical path method, fault tree analysis, keterlambatan proyek, reparasi kapal.

\section{PENDAHULUAN}

$\mathrm{P}$ ADA era globalisasi saat ini, dimana perkembangan industri berkembang pesat dan Indonesia yang merupakan negara kepulauan terbesar, menjadikannya sebagai wilayah strategis dalam mengembangkan usaha industri jasa transportasi laut yang memberikan manfaat sangat besar bagi perpindahan suatu barang melalui perairan. Pada gambar 1 menunjukkan armada pelayaran nasional mengalami pertumbuhan cukup signifikan pada periode 2005-2015. Pada 2005, jumlah armada pelayaran di Indonesia hanya 6.041, tapi pada 2015 telah meningkat menjadi 16.574 kapal.

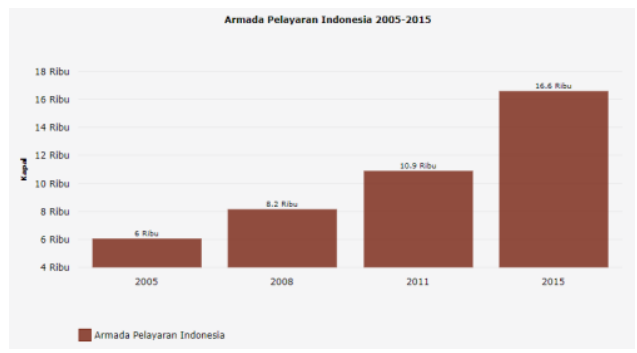

Gambar 1. Pertumbuhan jumlah armada pelayaran nasional 2005-2015
Kapal merupakan sarana transportasi yang sangat vital bagi perkembangan negara Indonesia. Peran penting kapal sangat terlihat dalam proses transportasi manusia, barang, dan juga dalam menjaga pertahanan negara Indonesia. Salah satu kapal yang akan dibahas dalam analisa ini adalah kapal kargo. Dari segi ekonomi kapal ini sangat membantu dalam proses pendistribusian barang antar pulau dan ekspor impor ke luar negeri sehingga negara memperoleh keuntungan yang baik jika kinerja kapal ini juga baik. Oleh sebab itu dalam rangka meningkatkan kinerja dan mutu dalam proses pendistribusian barang, diperlukan suatu proses pemeliharaan dan perbaikan kapal yang komprehensif dan holistik.

Waktu merupakan nilai elemen kritis dalam sebuah pelaksanaan proyek dan menjadi sebuah parameter penting dalam penyelenggaraan proyek yang dikenal sebagai sasaran proyek sehingga salah satu ukuran keberhasilan proyek ditentukan oleh penyelesaian proyek sesuai jangka waktu dan tanggal akhir yang telah ditetapkan dalam dokumen kontrak dan sesuai pula degan rencana dan spesifikasinya. Hasil akhir dalam proyek tidak boleh melewati batas waktu yang telah ditentukan.

Perencanaan waktu sebuah proyek perbaikan selalu mengacu pada perkiraan saat rencana pembuatan jadwal dibuat (schedule master), karena itu masalah dapat timbul apabila ada ketidaksesuaian antara rencana yang telah dibuat dengan pelaksanaan di lokasi proyek. Pada perencanaan yang cermat, dapat disusun penjadwalan proyek yang tepat yang sesuai dengan kondisi lapangan. Perencanaan proyek meliputi penjadwalan dan pembagian waktu untuk seluruh kegiatan proyek. Dengan adanya penjadwalan proyek yang sistematis, maka jadwal proyek lebih terarah dan dapat menghindari masalah yang dapat merugikan proyek.

Menganalisa berbagai faktor penyebab terjadinya keterlambatan pada proyek perbaikan merupakan hal yang penting untuk menentukan pengaruh dan akibat yang ditimbulkan dari terjadinya keterlambatan proyek serta dapat membantu semua pihak yang terlibat dalam proyek agar proses perencanaan dan penjadwalan proyek dapat dilakukan lebih lengkap sehingga dapat meminimalkan dan menghindari terjadinya keterlambatan proyek.

Dalam studi ini akan dilakukan penelitian berfokus pada kapal kargo MV. Blossom Pescadores milik PT. Bandar 
Bahari Permai yang sudah beroperasi sejak 1997 dan diperbaiki oleh PT. PAL Indonesia. Pada perusahaan ini juga belum pernah ada penelitian yang membahas tentang keterlambatan proyek pada perbaikan kapal kargo, oleh sebab itu dalam penelitian ini akan dibuat analisa faktor penyebab keterlambatan proyek perbaikan kapal menggunakan metode fault tree analysis yang berfungsi sebagai landasan dalam penjadwalan ulang menggunakan critical path method.

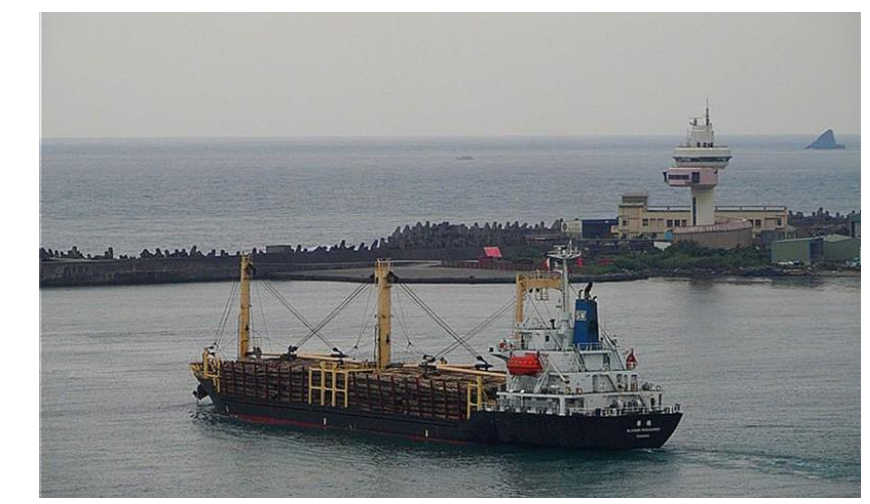

Gambar 2. MV. Blossom Pescadores

Penggunaan critical path inilah yang akan diteliti dalam manajemen suatu proyek, sehingga diharapkan akan adanya suatu keefektifan pada manajemen proyek tersebut karena [1] dalam prakteknya, jangka waktu perencanaan biasanya lebih besar dari waktu minimal yang diperlukan dalam pengerjaan reparasi kapal tersebut.

Tabel 1.

Data Umum Kapal

\begin{tabular}{|l|l|}
\hline Nama Kapal & MV. BLOSSOM PESCADORES \\
\hline Pemilik & PT. BANDAR BAHARI PERMAI \\
\hline Pelaksana & PT. PAL INDONESIA \\
\hline LOA & $100,74 \mathrm{M}$ \\
\hline LBP & $93,86 \mathrm{M}$ \\
\hline Breadth & $19 \mathrm{M}$ \\
\hline Depth & $8.8 \mathrm{M}$ \\
\hline GT & $4.334 \mathrm{~T}$ \\
\hline Klasifikasi & BKI \\
\hline Status & SS \\
\hline
\end{tabular}

\section{LANDASAN TEORI}

\section{A. Tinjauan Utama Kapal Kargo}

Kapal kargo atau dalam bahasa indonesia sering di sebut kapal barang, adalah sebuah alat transportasi laut yang di gunakan untuk mengangkut barang/kargo dari suatu daerah ke derah lainnya pada lautan skala lokal hingga internasional. Kapal kargo sesuai dengan tugasnya untuk mengangkat dan menurunkan barang di lengkapi dengan crane kapal atau alat bantu mengangkat barang dari atau ke kapal. Terdapat pula kapal kargo yang singgah di pelabuhan modern yang dilengkapi crane pelabuhan, maka kapal kargo tersebut tidak harus dilengkapi crane di kapal dengan alasan mendasar apabila tidak terdapat crane kapal maka dapat menambah ruang muat di kapal kargo. Dalam skala umur kapal kargo dirancang dengan umur pakai 25-30 tahun. Menurut Wahyudin (2011) Kapal kargo menurut jenis muatannya dapat di bagi menjadi 4 jenis kapal kargo yaitu :

1. General kargo vessels

2. Tankers

3. Dry-bulk carriers

4. Multipurpose vessels

\section{B. Reparasi Kapal}

Reparasi kapal merupakan sebuah tindakan pengembalian fungsi dan kondisi komponen kapal dalam rangka mempertahankan kelayakan pada kapal sehingga dapat beroperasi secara maksimal. Reparasi juga dapat berarti memperbaiki, mengganti komponen atau material yang rusak, dan termasuk ke dalam pemeliharaan kapal. Jenis-jenis pemeliharaan kapal, sebagai berikut:

1. Corrective maintenance

2. Preventive maintenance

3. Improvement maintenance

4. Predictive maintenance

5. Run to failure maintenance

Reparasi kapal sebagian besar dilakukan pada konstruksi dan permesinan kapal. Kedua komponen tersebut memiliki jenis dan tingkat kesulitan yang berbeda dalam reparasinya, sehingga membagi pekerjaan kapal dalan dua zona pengerjaan akan memudahkan analisa masalahnya. Hal ini dapat juga memudahkan proses pengidentifikasian list perbaikan kapal.

Proses perbaikan kapal sendiri mempunyai tiga tahapan, yaitu:

a. Persiapan perbaikan

b. Proses perbaikan

c. Pengecekan hasil perbaikan

Alur proses perbaikan kapal adalah sebagai berikut:

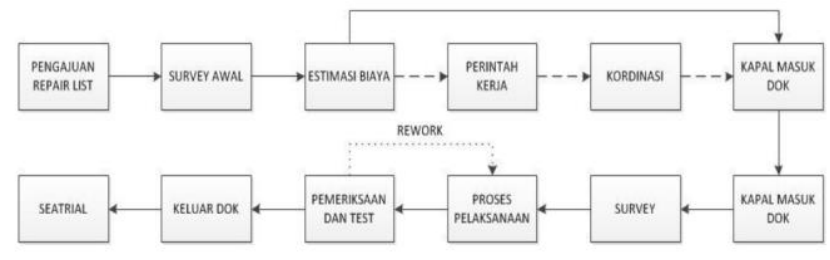

Gambar 3. Bagan pengerjaan reparasi kapal

Dapat diketahui bahwa proses perbaikan kapal adalah proses panjang yang melibatkan banyak pihak seperti galangan, klasifikasi, dan pemilik (owner). Berdasarkan pada Gambar 3, pada tahap awal perbaikan kapal pihak owner akan mengajukan list komponen kapal yang rusak dan perlu dilakukan perbaikan. Namun seiring dengan proses perbaikan kapal, akan ada beberapa tambahan pengerjaan yang diajukan galangan atau klasifikasi untuk dikerjakan. Nantinya tambahan pekerjaan tersebut harus disetujui oleh pihak owner.

Aktivitas dan kegiatan yang dilakukan dalam proses perbaikan kapal berbeda-beda tergantung jenis survey yang dilakukan. Jenis survey itu sendiri dibedakan berdasarkan 
waktu dan kebutuhan dari kapal tersebut. Beberapa jenis survey berdasarkan klasifikasi yang umum adalah:

1. Annual survey, survey yang dilakukan setahun sekali

2. General survey, survey yang dilakukan empat tahun sekali

\section{Emergency Survey}

Kegiatan survey yang dilakukan pada setiap docking berbeda-beda sesuai dengan peraturan klasifikasi dan kebutuhan dari kapal tersebut. Namun berdasarkan rules dari klasifikasi, maka setiap docking kapal akan dilakukan perbaikan berupa:

1. Perbaikan dan perawatan konstruksi kapal

2. Perbaikan dan perawatan lambung

3. Perbaikan dan perawatan mesin.

4. Perbaikan dan perawatan outfitting.

5. Perbaikan dan perawatan sistem perpipaan.

6. Perbaikan dan perawatan sistem kelistrikan.

\section{Fault Tree Analysis}

Fault Tree Analysis adalah teknik analisis sistem digunakan untuk menentukan akar penyebab permasalahan dan kemungkinan terjadinya kejadian tertentu yang tidak diinginkan. FTA digunakan untuk mengevaluasi sistem dinamis yang kompleks dan besar untuk memahami dan mencegah potensi masalah. Menggunakan metodologi yang ketat dan terstruktur, FTA memungkinkan menganalisa sistem untuk model kombinasi unik dan peristiwa kesalahan yang dapat menyebabkan kejadian yang tidak diinginkan terjadi [2].

Jadi, metode Fault Tree Analysis ini mengembangkan jalan kesalahan logis dari kejadian yang tidak diinginkan yang berada di atas (disebut Top Event) untuk semua akar penyebab yang mungkin terjadi pada bagian bawahnya. Kekuatan FTA adalah bahwa hal itu mudah dilakukan, mudah dimengerti, memberikan sistem wawasan yang bermanfaat, dan menunjukkan semua kemungkinan penyebab masalah yang diselidiki.

Struktur Fault Tree seperti pada gambar 3.1 yang telah dilengkapi dapat digunakan untuk menentukan signifikansi dari kesalahan peristiwa dan kemungkinan mereka terjadinya. Validitas tindakan yang dilakukan untuk menghilangkan atau mengontrol kesalahan peristiwa dapat ditingkatkan dalam keadaan tertentu dengan mengukur Fault Tree dan melakukan evaluasi numerik.

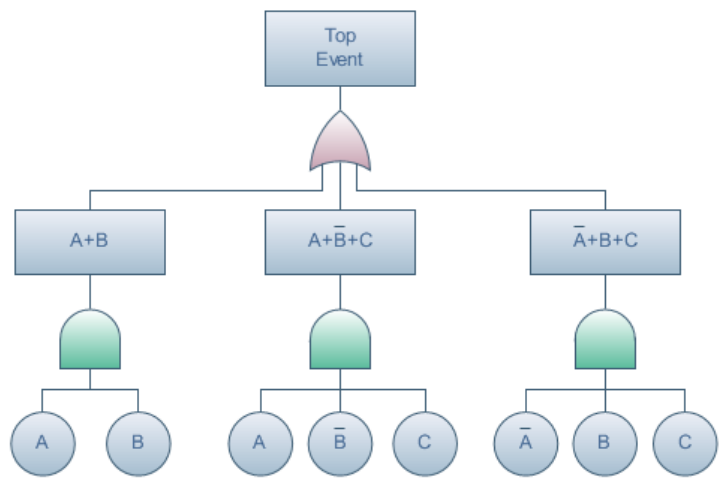

Gambar 4. Fault Tree Concept
Ada delapan langkah dasar yang diperlukan untuk melakukan FTA lengkap dan akurat, seperti yang ditunjukkan gambar 5.

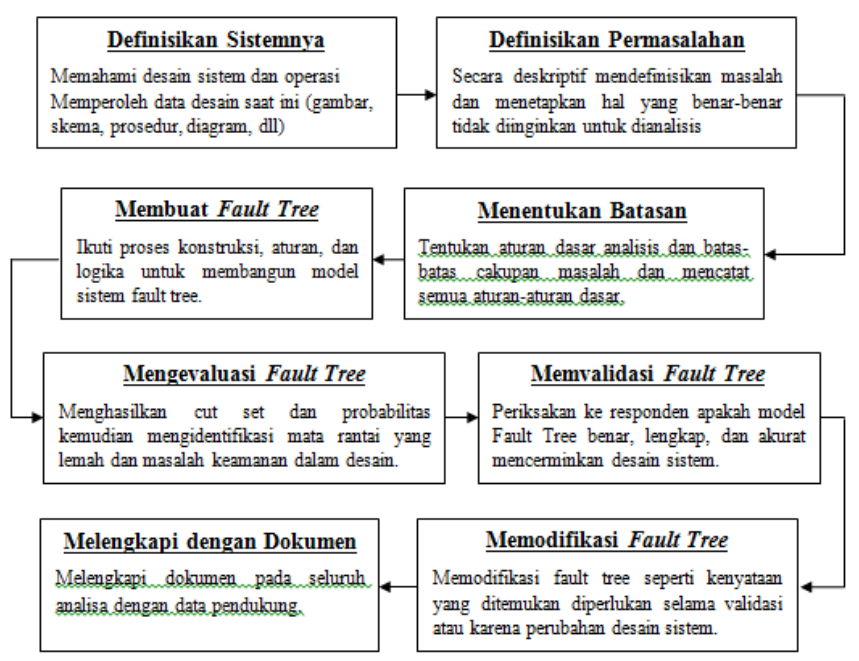

Gambar 5. Proses Fault Tree Analysis

\section{Critical Path Method}

Critical Path Method (CPM) adalah teknik manajemen proyek yang menggunakan hanya satu faktor waktu per kegiatan. Merupakan jalur tercepat untuk mengerjakan suatu proyek, dimana setiap proyek yang termasuk pada jalur ini tidak diberikan waktu jeda/istirahat untuk pengerjaannya. Dengan asumsi bahwa estimasi waktu tahapan kegiatan proyek dan ketergantungannya secara logis sudah benar. Jalur kritis berkonsentrasi pada timbal balik waktu dan biaya. Jalur kritis merupakan jalur yang terdiri dari kegiatan-kegiatan yang bila terlambat akan mengakibatkan keterlambatan penyelesaian proyek. Dalam CPM (Critical Path Method) dikenal EET (Earliest Event Time), LET (Latest Event Time), Total Float, Free Float, dan Independent Float. Dalam metode CPM juga akan mendapatkan lintasan kritis yang menghubungkan kegiatan kritis yang tidak boleh terhambat pelaksanaannya.

\section{ANALISA PEMBAHASAN DAN HASIL}

\section{A. Pengumpulan data}

Dalam penelitian studi ini, studi kasus yang diambil adalah proyek perbaikan kapal MV. Blossom di PT. PAL Indonesia.

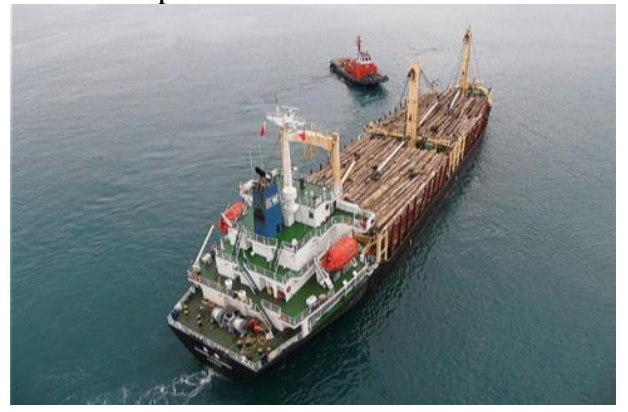

Gambar 6. Proyek Perbaikan Kapal MV. Blossom 
Studi ini dilakukan untuk mencari faktor-faktor dan dampak keterlambatan, serta membuat penjadwalan ulang agar bisa dijadikan sebagai acuan untuk waktu perbaikan kapal yang ideal.

Proyek ini direncanakan selesai dalam 21 hari, tetapi pada kenyataannya terjadi keterlambatan sampai membutuhkan 101 hari dalam pengerjaannya. Untuk proses perbaikan kapal yang semula direncanakan dimulai akhir bulan Januari 2017 dan selesai pada awal bulan Februari 2017, harus selesai pada awal bulan Mei 2017.

Tabel 2

Tabel Aktivitas Utama Proyek Perbaikan Kapal MV. Blossom

\begin{tabular}{|c|l|c|c|c|}
\hline No. & \multicolumn{1}{|c|}{ Aktivitas } & $\begin{array}{c}\text { Rencana } \\
\text { (hari) }\end{array}$ & $\begin{array}{c}\text { Realisasi } \\
\text { (hari) }\end{array}$ & $\begin{array}{c}\text { Terlambat } \\
\text { (hari) }\end{array}$ \\
\hline 1 & General Service & 21 & 101 & 80 \\
\hline 2 & Lambung & 13 & 20 & 7 \\
\hline 3 & Top Structure & 13 & 67 & 54 \\
\hline 4 & Cleaning Tangki & 13 & 44 & 31 \\
\hline 5 & Aluminium Anode & 6 & 6 & 0 \\
\hline 6 & Jangkar, Rantai Jangkar dan Bak Rantai & 10 & 10 & 0 \\
\hline 7 & Sea Chest Gratting & 10 & 10 & 0 \\
\hline 8 & Bottom plug & 2 & 2 & 0 \\
\hline 9 & Sea Valve & 7 & 7 & 0 \\
\hline 10 & Tail Shaft \& Propeller & 13 & 13 & 0 \\
\hline 11 & Rudder Blade & 12 & 13 & 1 \\
\hline 12 & Pengukuran Ketebalan & 3 & 4 & 1 \\
\hline 13 & Replating & 12 & 12 & 0 \\
\hline
\end{tabular}

\section{B. Pengolahan Data}

Dalam melakukan pengolahan data untuk mencari faktor keterlambatan dalam bentuk fault tree analysis Langkah yang dilakukan adalah melakukan input dari software ini berupa data basic event dan probabilitas dari hasil wawancara dan kuesioner. Data kemudian diproses dalam bentuk diagram FTA sehingga akan muncul output berupa diagram FTA yang telah tersusun rapi.

\section{Fault Tree Analysis}

Proyek reparasi kapal MV. Blossom yang dibagi menjadi 3 cabang utama yaitu pekerjaan persiapan, pekerjaan konstruksi dan pengadaan, dan sistem manajemen. Dari cabang pekerjaan persiapan terdapat 1 proses yang menyebabkan keterlambatan, dari cabang pekerjaan konstruksi dan pengadaan terdapat 3 cabang utama dan dari cabang sistem manajemen terdapat 2 cabang utama. Dari setiap cabang ini akan dijabarkan lagi menjadi lebih rinci mengenai akar permasalahan dari masingmasing kejadian.

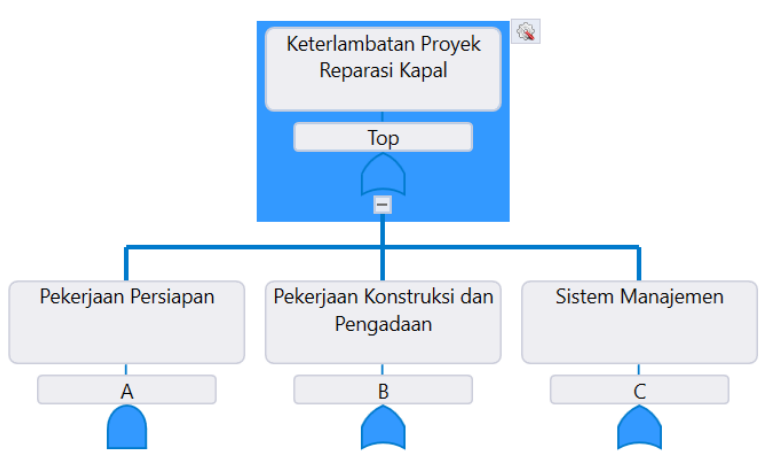

Gambar 7 Diagram FTA Proyek Reparasi Kapal MV. Blossom yang Mengalami Keterlambatan
Salah satu penjabaran cabang utama pada Proyek reparasi kapal ini adalah Manajemen yang kurang baik yang dapat mengganggu proses pelaksanaan suatu proyek. Ada beberapa faktor yang dapat mempengaruhi manajemen, antara lain pengendalian manajemen yang kurang efektif, plan schedule proyek tidak terealisasi, dan kurangnya koordinasi lapangan.

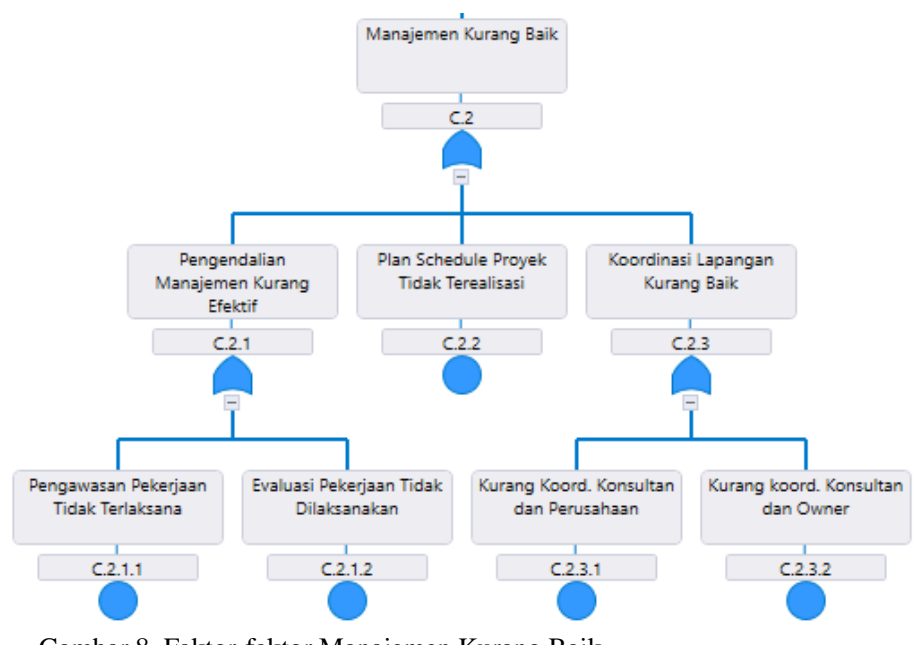

Gambar 8. Faktor-faktor Manajemen Kurang Baik

\section{Minimal Cut Set}

Langkah yang dilakukan berikutnya setelah membuat diagram fault tree analysis (FTA) adalah menetukan cut set. Cut set adalah kombinasi kegagalan pada kejadian dasar (basic event) atau kombinasi pembentuk pohon kesalahan yang jika semua terjadi maka dapat menyebabkan peristiwa puncak terjadi.Berikut merupakan basic event dari skema fault tree

Tabel 3

Basic Event FTA

\begin{tabular}{|c|c|l|}
\hline No. & $\begin{array}{c}\text { Kode } \\
\text { Kejadian }\end{array}$ & \multicolumn{1}{c|}{ Nama Kejadian } \\
\hline 1 & A.1.1 & Docking darurat kapal lain \\
\hline 2 & B.1.1.1 & Material import \\
\hline 3 & B.1.1.2 & Material belum tersedia di pasaran \\
\hline 4 & B.1.1.3 & Kualitas material kurang baik sehingga dilakukan pemesanan ulang \\
\hline 5 & B.1.1.4 & Ukuran dan spesifikasi material tidak tersedia di pasaran \\
\hline 6 & B.1.1.5 & Durasi pengiriman material lama \\
\hline 7 & B.2.1.1 & Peralatan jarang dirawat \\
\hline 8 & B.2.1.2 & Pemakaian peralatan berlebihan \\
\hline 9 & B.2.2 & Peralatan kerja terbatas \\
\hline 10 & B.3.1 & Rekruitmen karyawan dibatasi \\
\hline 11 & B.3.2 & Karyawan banyak yang pensiun \\
\hline 12 & B.3.3 & Regenerasi karyawan belum ada \\
\hline 13 & B.3.4 & Jumlah tenaga kerja kurang \\
\hline 14 & C. 1.1 & Produk diterima dengan catatan \\
\hline 15 & C. 2.1 .1 & Pengawasan pekerjaan tidak terlaksana \\
\hline 16 & C. 2.1 .2 & Evaluasi pekerjaan tidak dilaksanakan \\
\hline 17 & C. 2.2 & Plan schedule proyek tidak terealisasi \\
\hline 18 & C. 2.3 .1 & Kurang koord. konsultan dan perusahaan \\
\hline 19 & C. 2.3 .2 & Kurang koord. konsultan dan owner \\
\hline
\end{tabular}

Langkah awal pengerjaan adalah menentukan intermediate event, faktor dari basic event FTA, lalu menentukan probabilitas dari masing-masing basic event tersebut dimana hasil probabilitas ini didapat dari hasil kuesioner dan wawancara dengan responden, lalu didapatkan hasil dari minimal cut set dari masing-masing cabang diagram FTA. 
Tabel 4.

Probabilitas Event

\begin{tabular}{|c|c|c|}
\hline No. & Nama Kejadian & Probabilitas \\
\hline A. & \multicolumn{2}{|l|}{ Minimal Cut Set pada Pekerjaan Persiapan } \\
\hline 1 & Docking darurat kapal lain & 0.00428 \\
\hline \multicolumn{2}{|r|}{ TOTAL } & 0.00428 \\
\hline B. & \multicolumn{2}{|l|}{ Minimal Cut Set pada Pekerjaan Konstruksi dan Pengadaan } \\
\hline 1 & Material import & 0.00521 \\
\hline 2 & Material belum tersedia di pasaran & 0.00138 \\
\hline 3 & Kualitas material kurang baik sehingga dilakukan pemesanan ulang & 0.00156 \\
\hline 4 & Ukuran dan spesifikasi material tidak tersedia di pasaran & 0.00185 \\
\hline 5 & Durasi pengiriman material lama & 0.00161 \\
\hline 6 & Peralatan jarang dirawat & 0.02251 \\
\hline 7 & Pemakaian peralatan berlebihan & 0.01152 \\
\hline 8 & Peralatan kerja terbatas & 0.03321 \\
\hline 9 & Rekruitmen karyawan dibatasi & 0.01189 \\
\hline 10 & Karyawan banyak yang pensiun & 0.00806 \\
\hline 11 & Regenerasi karyawan belum ada & 0.01106 \\
\hline 12 & Jumlah tenaga kerja kurang & 0.01239 \\
\hline \multicolumn{2}{|r|}{ TOTAL } & 0.12225 \\
\hline C. & \multicolumn{2}{|l|}{ Minimal Cut Set pada Sistem Manajemen } \\
\hline 1 & Produk diterima dengan catatan & 0.00083 \\
\hline 2 & Pengawasan pekerjaan tidak terlaksana & 0.00669 \\
\hline 3 & Evaluasi pekerjaan tidak dilaksanakan & 0.00685 \\
\hline 4 & Plan schedule proyek tidak terealisasi & 0.00645 \\
\hline 5 & Kurang koord. konsultan dan perusahaan & 0.00643 \\
\hline 6 & Kurang koord. konsultan dan owner & 0.00643 \\
\hline \multicolumn{2}{|r|}{ TOTAL } & 0.03368 \\
\hline
\end{tabular}

Dari probabilitas event diatas dapat diketahui masingmasing minimal cut set dari fault tree analysis (FTA). Untuk minimal cut set pada pekerjaan persiapan memiliki probabilitas sebesar 0,00428. Kemudian untuk minimal cut set pada pekerjaan konstruksi dan pengadaan memiliki probabilitas sebesar 0.12225 , sedangkan untuk minimal cut set pada sistem manajemen memiliki probabilitas sebesar 0,03368. Jadi jumlah total probabilitas minimal cut set untuk top event adalah 1,60181.

\section{INTERMEDIATE EVENT}

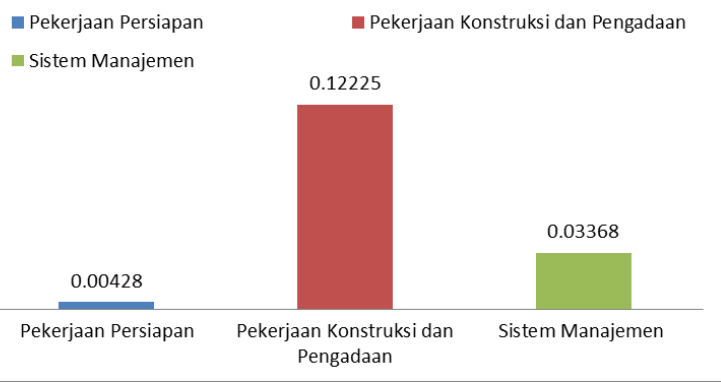

Gambar 9. Grafik Perbandingan Probabilitas

"Pekerjaan konstruksi dan pengadaan "mempunyai probabilitas yang lebih tinggi dari "Pekerjaan persiapan" dan "Sistem manajemen". Ini dikarenakan proses reparasi meliputi berbagai macam hal mulai dari konstruksi hingga pengadaan. Permasalahan utama dalam keterlambatan ini adalah peralatan kerja terbatas, peralatan jarang dirawat, dan jumlah tenaga kerja kurang.

\section{E. Penjadwalan ulang menggunakan Critical Path Methode}

Berikut adalah tabel yang menunjukkan tentang berbagai macam kegiatan pada proyek reparasi serta ketergantungan (dependency) dan durasi dari masing-masing kegiatan yang akan digunakan sebagai dasar dan dan pedoman dalam pembuatan network planning reparasi kapal.

Tabel 5

Ketergantungan dan Durasi Tiap Kegiatan Proyek Reparasi

\begin{tabular}{|l|c|c|c|}
\hline \multicolumn{1}{|c|}{ Nama Kegiatan } & Notasi & Ketergantungan & Durasi \\
\hline General services & A & - & 1 hari \\
\hline Lambung & B & A & 12 hari \\
\hline Top Structure & C & A & 17 hari \\
\hline Cleaning Tangki & D & A & 14 hari \\
\hline Aluminium anode & E & B & 5 hari \\
\hline Jangkar, rantai jangkar, dan bak rantai & F & B & 9 hari \\
\hline Sea chest grating & G & B & 9 hari \\
\hline Bottom plug & H & C & 2 hari \\
\hline Sea valve & I & E,H & 6 hari \\
\hline Tail shaft \& Propeller & J & E & 13 hari \\
\hline Rudder blade & K & D & 12 hari \\
\hline Pengukuran Ketebalan & L & C & 10 hari \\
\hline Replating & M & I, $, \mathrm{K}, \mathrm{L}$ & 10 hari \\
\hline
\end{tabular}

Dari tabel diatas, dapat dibuat network diagram awal proses reparasi kapal seperti yang terlampir di lampiran. Setelah membuat network diagram, langkah selanjutnya adalah menentukan earliest event time (EET) berdasarkan perhitungan earliest start (ES) dan earliest finish (EF) dan menentukan latest event time (LET) berdasarkan perhitungan latest start (LS) dan latest finish (LF) pada seluruh kegiatan dalam network diagram tersebut dengan tujuan untuk menghitung total durasi proyek serta menghitung total slack setiap kegiatan untuk menentukan lintasan kritis.

Tabel 6

Perhitungan Maju Kegiatan Proyek Reparasi

\begin{tabular}{|c|l|c|c|c|}
\hline Notasi & \multicolumn{1}{|c|}{ Kegiatan } & Durasi & ES & EF \\
\hline A & General services & 1 hari & 0 & 1 \\
\hline B & Lambung & 12 hari & 1 & 13 \\
\hline C & Top Structure & 21 hari & 1 & 18 \\
\hline D & Cleaning Tangki & 14 hari & 1 & 15 \\
\hline E & Aluminium anode & 5 hari & 13 & 18 \\
\hline F & Jangkar, rantai jangkar, dan bak rantai & 9 hari & 13 & 22 \\
\hline G & Sea chest grating & 9 hari & 13 & 22 \\
\hline H & Bottom plug & 2 hari & 22 & 24 \\
\hline I & Sea valve & 6 hari & 18 & 24 \\
\hline J & Tail shaft \& Propeller & 13 hari & 18 & 31 \\
\hline K & Rudder blade & 12 hari & 15 & 27 \\
\hline L & Pengukuran Ketebalan & 10 hari & 18 & 28 \\
\hline M & Replating & 10 hari & 31 & 41 \\
\hline
\end{tabular}

Dari perhitugan diatas dapat diketahui Earliest Event Time (EET) dan Latest Event Time (LET) dari Critical Path Method.

Tabel 7

Perhitungan EET dan LET Kegiatan Proyek Reparasi

\begin{tabular}{|c|c|c|c|c|c|}
\hline Notasi & Nama Kegiatan & Durasi & Ketergantungan & EET & LET \\
\hline $\mathrm{A}$ & General services & 1 hari & \begin{tabular}{|c|c|}
- & \\
\end{tabular} & 1 & 1 \\
\hline $\mathrm{B}$ & Lambung & 12 hari & $\mathrm{A}$ & 13 & 13 \\
\hline $\mathrm{C}$ & Top Structure & 17 hari & $\mathrm{A}$ & 18 & 21 \\
\hline $\mathrm{D}$ & Cleaning Tangki & 14 hari & $\mathrm{A}$ & 15 & 19 \\
\hline $\mathrm{E}$ & Aluminium anode & 5 hari & $\mathrm{B}$ & 18 & 18 \\
\hline $\mathrm{F}$ & Jangkar, rantai jangkar, dan bak rantai & 9 hari & $\mathrm{B}$ & 22 & 29 \\
\hline $\mathrm{G}$ & Sea chest grating & 9 hari & $\mathrm{B}$ & 22 & 29 \\
\hline $\mathrm{H}$ & Bottom plug & 2 hari & $\mathrm{C}$ & 24 & 31 \\
\hline $\mathrm{I}$ & Sea valve & 6 hari & $\mathrm{E}, \mathrm{H}$ & 24 & 31 \\
\hline $\mathrm{J}$ & Tail shaft \& Propeller & 13 hari & $\mathrm{E}$ & 31 & 31 \\
\hline $\mathrm{K}$ & Rudder blade & 12 hari & $\mathrm{D}$ & 27 & 31 \\
\hline $\mathrm{L}$ & Pengukuran Ketebalan & 10 hari & $\mathrm{C}$ & 28 & 31 \\
\hline $\mathrm{M}$ & Replating & 10 hari & $\mathrm{I}, \mathrm{J}, \mathrm{K}, \mathrm{L}$ & 41 & 41 \\
\hline
\end{tabular}

Jalur kritis adalah jalur yang terdiri dari rangkaian kegiatan pada proyek yang jika salah satu kegiatan dipercepat akan 
mempengaruhi durasi proyek secara keseluruhan. Kegiatan yang berada di jalur ini disebut peristiwa kritis. Kegiatan pada jalur kritis tidak memiliki nilai slack. Dibawah ini adalah tabel slack untuk masing-masing kegiatan.

Tabel 8

Total Slack Kegiatan Proyek Reparasi

\begin{tabular}{|c|l|c|c|c|c|c|}
\hline Notasi & \multicolumn{1}{|c}{ Nama Kegiatan } & Durasi & Ketergantungan & EET & LET & Slack \\
\hline A & General services & 1 hari & - & 1 & 1 & 0 \\
\hline B & Lambung & 12 hari & A & 13 & 13 & 0 \\
\hline C & Top Structure & 17 hari & A & 18 & 21 & 3 \\
\hline D & Cleaning Tangki & 14 hari & A & 15 & 19 & 4 \\
\hline E & Aluminium anode & 5 hari & B & 18 & 18 & 0 \\
\hline F & Jangkar, rantai jangkar, dan bak rantai & 9 hari & B & 22 & 29 & 7 \\
\hline G & Sea chest grating & 9 hari & B & 22 & 29 & 7 \\
\hline H & Bottom plug & 2 hari & C & 24 & 31 & 7 \\
\hline I & Sea valve & 6 hari & E,H & 24 & 31 & 7 \\
\hline J & Tail shaft \& Propeller & 13 hari & E & 31 & 31 & 0 \\
\hline K & Rudder blade & 12 hari & D & 27 & 31 & 4 \\
\hline L & Pengukuran Ketebalan & 10 hari & C & 28 & 31 & 3 \\
\hline M & Replating & 10 hari & I,J,K,L & 41 & 41 & 0 \\
\hline
\end{tabular}

Dari perhitungan diatas dapat dilihat bahwa jalur yang tidak memiliki slack atau memiliki nilai slack $=0$ adalah jalur yang terdiri dari kegiatan A-B-E-J-M.

\section{F. Skenario Ketelambatan}

Berdasarkan pengalaman proyek reparasi kapal yang sudah pernah dilakukan sebelumnya, ada 3 penyebab keterlambatan yang sering terjadi di lapangan, yaitu:

1. Keterlambatan pekerjaan Lambung (B) selama 8 hari

Pekerjaan lambung meliputi banyak pekerjaan yang saling terkait dan berurutan dan harus sesuai prosedur, sehingga menurut pengalaman di lapangan sangat bergantung pada jumlah alat yang digunakan.

2. Keterlambatan pekerjaan Top Structure (C) selama 16 hari Pekerjaan top structure adalah proses pekerjaan pembersihan konstruksi kapal bagian atas termasuk cargo hole dan hatch cover, sehingga memakan waktu lama.

3.Keterlambatan pekerjaan Cleaning Tangki (D) selama 8 hari Sebagian pekerjaan cleaning tangki dilakukan secara manual, sehingga dibutuhkan alokasi jumlah pekerja yang cukup banyak.

Tabel 9

Skenario keterlambatan pekerjaan lambung

\begin{tabular}{|c|c|c|c|c|}
\hline Notasi & Nama Kegiatan & Durasi & Ketergantungan & EET \\
\hline $\mathrm{A}$ & General services & 1 hari & \begin{tabular}{|c|}
- \\
\end{tabular} & 1 \\
\hline $\mathrm{B}$ & Lambung & 20 hari & $\mathrm{A}$ & 21 \\
\hline $\mathrm{C}$ & Top Structure & 17 hari & $\mathrm{A}$ & 18 \\
\hline $\mathrm{D}$ & Cleaning Tangki & 14 hari & $\mathrm{A}$ & 15 \\
\hline $\mathrm{E}$ & Aluminium anode & 5 hari & $\mathrm{B}$ & 26 \\
\hline $\mathrm{F}$ & Jangkar, rantai jangkar, dan bak rantai & 9 hari & $\mathrm{B}$ & 30 \\
\hline $\mathrm{G}$ & Sea chest grating & 9 hari & $\mathrm{B}$ & 30 \\
\hline $\mathrm{H}$ & Bottom plug & 2 hari & $\mathrm{C}$ & 32 \\
\hline $\mathrm{I}$ & Sea valve & 6 hari & $\mathrm{E}, \mathrm{H}$ & 32 \\
\hline $\mathrm{J}$ & Tail shaft \& Propeller & 13 hari & $\mathrm{E}$ & 39 \\
\hline $\mathrm{K}$ & Rudder blade & 12 hari & $\mathrm{D}$ & 27 \\
\hline $\mathrm{L}$ & Pengukuran Ketebalan & 10 hari & $\mathrm{C}$ & 28 \\
\hline $\mathrm{M}$ & Replating & 10 hari & $\mathrm{I}, \mathrm{J}, \mathrm{K}, \mathrm{L}$ & 49 \\
\hline
\end{tabular}

Pada skenario keterlambatan pekerjaan lambung, diasumsikan bahwa pekerjaan Lambung terlambat selama 8 hari, dari durasi awal 12 hari menjadi 20 hari.

Hasil dari scenario pertama adalah pekerjaan Aluminium Anode (E), Jangkar, Rantai Jangkar, dan Bak Rantai (F), Sea Chest Grating (G), Bottom Plug (H), Sea Valve (I), Tailshaft dan Propeller (J), dan Replating (M) akan mengalami keterlambatan selama 8 hari karena terpengaruh keterlambatan dari pekerjaan Lambung. Maka dari itu bisa ditarik kesimpulan bahwa keterlambatan pekerjaan Lambung membuat durasi total proyek terlambat selama 8 hari.

\section{KESIMPULAN}

Dari hasil penelitian yang dilakukan dalam studi ini dapat diambil kesimpulan sebagai berikut:

1. Berdasarkan hasil perhitungan minimal cut set, didapatkan tiga nilai probabilitas terbesar basic event penyebab keterlambatan proyek reparasi kapal, yaitu:

a. Peralatan kerja terbatas, sebesar 0.03321

b. Peralatan jarang dirawat, sebesar 0.02251

c. Jumlah tenaga kerja kurang, sebesar 0.01239

Sehingga didapatkan probabilitas keseluruhan dari keterlambatan proyek reparasi kapal menggunakan metode fault tree analysis (FTA) adalah 0.16021, dengan rincian sebagai berikut:

a. Pekerjaan persiapan, sebesar 0.00428

b. Pekerjaan konstruksi dan pengadaan, sebesar 0.12225

c. Sistem manajemen, sebesar 0.03368

2. Berdasarkan perhitungan lintasan kritis, total durasi proyek reparasi kapal dapat dipercepat dari 101 hari menjadi 41 hari dengan asumsi kegiatan pekerjaan dilakukan secara runtut tanpa adanya hambatan.

\section{DAFTAR PUSTAKA}

[1] S. Joko, Manajemen Produksi dan Operasi. Malang: Universitas Muhammadiyah Malang, 2001.

[2] E. A. Clifton, Hazard Analysis Techniques for System Safety. New Jersey: John Wiley \& Sons, Inc. Hoboken, 2005. 